\title{
Detecção de Leptospira pomona em sêmen bovino por eletroforese capilar fluorescente
}

Francisca Elda Ferreira DIAS ${ }^{1}$ Sérgio Morais $\mathrm{AOKI}^{2}$ Lígia Garcia MESQUITA ${ }^{3}$ Caris Maroni NUNES ${ }^{3}$ José Fernando GARCIA ${ }^{3}$

\section{Correspondência para:} JOSÉ FERNANDOGARCIA

Laboratório de Bioquímica e Biologia Molecular Animal

Universidade Estadual Paulista Rua Clóvis Pestana, 793, Jardim Dona Amélia

16050-680 - Araçatuba-SP jfgarcia@terra.com.br

Recebido para publicação: 06/07/2004 Aprovado para publicação: 01/06/2005

\author{
1 - Departamento de Medicina Veterinária Preventiva e Reprodução Animal \\ da Universidade Estadual Paulista, Jaboticabal - SP \\ 2 - Departamento de Genética do Instituto de Biociências da Universidade \\ Estadual Paulista, Botucatu - SP \\ 3 - Departamento de Apoio, Produção e Saúde Animal da Universidade \\ Estadual Paulista, Araçatuba - SP
}

\section{Resumo}

Este estudo pretendeu avaliar o limiar de detecção da técnica de PCR aliada à eletroforese capilar para diagnóstico da Leptospira pomona em sêmen bovino. Doses inseminantes livres de patógenos foram contaminadas experimentalmente com Leptospira pomona em escalas que variavam de $10^{0}$ a $10^{7}$ bactérias $/ \mathrm{ml}$ e submetidas à extração de DNA pelo método de fenol/clorofórmio. Após a reação de PCR, a visualização dos fragmentos foi realizada em três tipos de eletroforese: agarose $2 \%$ sob luz UV, acrilamida $8 \%$ corado com prata e eletroforese capilar fluorescente. A detecção de DNA de Leptospirapomona em sêmen bovino através de eletroforese capilar fluorescente foi possível a partir de concentração de $10^{2}$ bactérias $/ \mathrm{ml}$. Nos métodos de eletroforese em agarose $2 \%$, observou-se limite de detecção de $10^{4}$ bactérias $/ \mathrm{ml} \mathrm{e} \mathrm{em}$ gel de poliacrilamida $8 \%$ o limite de detecção foi de $10^{2}$ bactérias $/ \mathrm{ml}$. A eletroforese capilar demonstrou ser uma alternativa eficaz e rápida na detecção de DNA de Leptospira em sêmen bovino podendo ser uma valiosa ferramenta para controle de qualidade do sêmen produzido em centrais de inseminação artificial dada a facilidade de automação desse processo.

\section{Introdução}

A leptospirose é uma zoonose de distribuição mundial causada por uma espiroqueta, classificada na família Leptospiracea, gênero Leptospira. Entre as várias doenças ligadas à reprodução, a leptospirose participa como uma das grandes responsáveis pela baixa produtividade do rebanho bovino, afetando de modo significativo a pecuária de um país, sua importância não é somente devida aos prejuízos econômicos e na cadeia de produção animal, mas também como causa de riscos à saúde humana ${ }^{1,2}$.

As perdas reprodutivas causadas pela Leptospira interrogans em bovinos, nas suas fases aguda e crônica, são caracterizadas principalmente por: aborto, infertilidade, retenção placentária, queda na produção de leite, mastite e infecção renal ${ }^{3}$.

O diagnóstico definitivo da infecção por Leptospira spp é usualmente dado pelo isolamento e cultivo do agente infeccioso, o que pode demandar de semanas, ou na detecção de sua presença por métodos imunológicos, com variáveis sensibilidade e especificidade ${ }^{4,5,6}$.

Nos últimos anos, técnicas moleculares de diagnóstico embasadas na metodologia de PCR, constituíram importante avanço na detecção rápida de patógenos em diferentes tipos de amostras 7 . Diversos patógenos podem ser detectados com sucesso quando diagnosticados por PCR: Parvovirus canino, Herpervirus 1 bovino ${ }^{9,10,11}$, Chlamydia psittaci em amostras clinicas de aviário ${ }^{12}$ e Staphylococcus aureus no leite ${ }^{13}$ entre outros são exemplos disso.

Recentemente, a técnica de reação em 
cadeia pela polimerase (PCR) começou a ser aplicada para a detecção de agentes infecciosos no sêmen de bovinos, tornandose uma alternativa eficiente e promovendo o diagnóstico rápido e específico ${ }^{4,9,10}$. Trabalhos recentes ${ }^{14,15}$, demonstraram a viabilidade do diagnóstico de Leptospira por PCR no sêmen bovino.

O presente estudo teve como objetivo avaliar a sensibilidade e especificidade da técnica de PCR, aliada à eletroforese capilar, para detecção de Leptospira pomona em sêmen bovino contaminado experimentalmente.

\section{Materiais e Métodos}

O presente experimento foi desenvolvido no Laboratório de Bioquímica e Biologia Molecular Animal, localizado na Faculdade de Odontologia de Araçatuba curso de Medicina Veterinária da UNESP, Araçatuba, São Paulo, Brasil.

\section{Cepas padrão de Leptospira pomona}

Cepas de Leptospira pomona foram gentilmente cedidas pelo Laboratório IRFAQuímica e Biotecnologia Industrial Ltda, Porto Alegre, RS, Brasil. As bactérias foram inativadas pelo calor a $100{ }^{\circ} \mathrm{C}$ por 15 minutos. A concentração de bactérias foi determinada no laboratório de origem, pela contagem de células bacterianas em campo escuro.

\section{Sêmen bovino}

Amostras de sêmen bovino empregado para contaminação experimental com Leptospira pomona foram obtidas de um touro da raça Nelore da Central de Inseminação Artificial Lagoa da Serra, localizada no município de Sertãozinho, Estado de São Paulo. O sêmen foi testado por sorologia ou cultivo e apresentava resultado negativo para o agente em questão. Realizou-se a contagem de espermatozóides na amostra utilizando a câmara de Neubauer e procedeu-se a diluição em solução salina 0,9\% estéril para o volume final de $500 \mathrm{~mL}$, contento aproximadamente 3×107espermatozóides/ml (que constitui a dose inseminante padrão). Para determinar a menor concentração de DNA bacteriano capaz de ser detectada através da técnica de PCR, a contaminação experimental foi obtida por diluições serial em base $10\left(10^{7} \mathrm{a}\right.$ $10^{\circ}$ bactérias $/ \mathrm{ml}$ ) de Leptospira pomona.

\section{Extração de DNA}

A extração do DNA das suspensões contendo bactérias e sêmen bovino foi realizada segundo protocolo descrito Heinemann et al. ${ }^{15}$ com algumas modificações. As amostras foram centrifugadas a $13000 \mathrm{x}$ g por 1 hora. Em seguida resuspendeu-se o sedimento em 410 L de tampão de lise contendo $50 \mathrm{~mL}$ de lisozima $(20 \mathrm{mg} / \mathrm{mL}), 50 \mathrm{~mL}$ de proteinase $\mathrm{K}(20 \mathrm{mg} / \mathrm{mL}), 50 \mathrm{ml}$ de dodecilsulfato de sódio (SDS) $10 \%$ e $260 \mathrm{ml}$ de Acetato de Sódio $0,2 \mathrm{M}$ e incubou-se a $56{ }^{\circ} \mathrm{C}$. A integridade do DNA purificado foi constatada por eletroforese em gel de agarose $2 \%$ empregando brometo de etídeo como revelador ${ }^{16}$.

\section{Amplificação do DNA por PCR}

Foram utilizados os oligonucleotídeos iniciadores que amplificam 330 pares de base (pb) em Leptospira sp (LF5'GGCGGCGCGTCT'TAAACATG 3' marcado com substância fluorescente HEX e LR-5' TCCCCCCAT'TGAGCAAGAT'T 3) previamente descritos ${ }^{17}$.

As reações de PCR foram realizadas em volume total de $50 \mathrm{~mL}$ contendo $200 \mathrm{mM}$ Tris- $\mathrm{HCl} \mathrm{pH} 8,0 ; 2,5 \mathrm{mM}$ cloreto de magnésio; $1,25 \mathrm{mM}$ de cada desoxiribonucleotídeo trifosfatado (dNTPs); 10 pmol de cada oligonucleotídeo iniciador LF e LR; 0,5U de Taq DNA polimerase (Invitrogen, Brasil). Além disso, foram utilizados em cada experimento controles negativos contendo todos os reagentes exceto DNA para monitoramento de possíveis contaminações. As amostras foram submetidas a uma desnaturação inicial de 5 minutos a $95^{\circ} \mathrm{C}, 35$ ciclos de $95^{\circ} \mathrm{C}$ por $40 \mathrm{seg}, 55^{\circ} \mathrm{C}$ por $40 \mathrm{seg}, 72^{\circ} \mathrm{C}$ por 40 seg e extensão final $72^{\circ} \mathrm{C}$ por 5 minutos realizada 
em termociclador PTC-100 (MJ-Research ${ }^{\circledR}$ - USA).

\section{Análise dos Produtos de PCR}

Os fragmentos de DNA foram separados por eletroforese em gel de agarose $2 \%$ corado com brometo de etídeo, gel de poliacrilamida $8 \%$ corado com prata ${ }^{16}$ e por eletroforese capilar em equipamento automático de análise de fragmentos de DNA (ABI-310 Applied Biosystem ${ }^{\circledR}$ ).

\section{Resultados e Discussão}

Recentemente, técnicas de PCR para detecção de bactérias patogênicas vêm sendo bastante utilizadas por sua precisão e sensibilidade. Estas vantagens permitem identificação extremamente específica, permitindo distinguir os diferentes genótipos de bactérias ${ }^{1,14,15,18,19,20}$.

A figura 1 apresenta os resultados da amplificação por PCR para detecção de Leptospira pomona em sêmen bovino infectado experimentalmente com diferentes diluições desta bactéria. Para determinar o limite de detecção de Leptospira através da PCR foi realizada diluição seriada na base $10 \mathrm{em}$ amostra de sêmen bovino livres de Leptospira, sendo possível detectar até a diluição contendo $10^{2}$ bactérias $/ \mathrm{ml}$. Este resultados são semelhantes aos obtidos por Heinemann $^{5}$, cujo limiar de detecção foi 10 bactérias $/ \mathrm{ml}$ em diluições desta bactéria em cultivo puro e sêmen contaminado experimentalmente.

A visualização dos produtos de PCR foi realizada através de três sistemas eletroforéticos: agarose $2 \%$ (Figura 1A), acrilamida $8 \%$ (Figura 1B) e eletroforese capilar em equipamento automático de análise de fragmentos de DNA-ABI310Applied Biosystem ${ }^{\circledR}$ (Figura 1C). Através dos oligonucletídeos iniciadores LF e LR observou-se a amplificação de um fragmento de 330 pares de base (bp) do DNA de Leptospira pomona.

Utilizando os métodos de eletroforese tradicionais (agarose 2\% e poliacrilamida $8 \%$ ), foi possível detectar até a concentração de $10^{4}$ bactérias $/ \mathrm{ml}$ e $10^{2}$ bactérias $/ \mathrm{ml}$ em cada método respectivamente. Já através da eletroforese capilar foi possível detectar até a concentração de $10^{2}$ bactérias $/ \mathrm{ml}$, sendo que este método mostrou-se mais rápido, prático e mais sensível podendo ser utilizado simultâneamente para a detecção não só de bactérias, mas também outros agentes microbianos que possam concorrer na infecção as amostras de sêmen.

A detecção do DNA de bactérias patogênicas após reação de PCR é rotineiramente realizada por gel de eletroforese. Porém o gel de eletroforese é regularmente pouco sensível e requer longo tempo para separação o que impõe limitações a total eficiência das técnicas de PCR para análise rápida, específica e automatizada ${ }^{21}$. Segundo Song, Mobley e $V_{o}-D_{i n h}^{22}$ a alta velocidade e sensibilidade são os mais importantes fatores a serem considerados na detecção de bactérias porque a presença de até mesmo um único organismo patogênico pode resultar em infecção.

A eletroforese capilar pode ser uma alternativa na detecção de DNA de Leptospira pomona, tendo se mostrado uma maneira eficaz e rápida de detecção destes patógenos, quando comparado aos sistemas de eletoforeticos tradicionais. Além disso o acoplamento de outros patógenos a um teste rápido utilizando essa metodologia, pode constituir-se numa excelente ferramenta para o controle de qualidade sanitário em centrais de inseminação artificial e de transferência de embriões.

\section{Conclusões}

Podemos concluir que a eletroforese capilar é uma valiosa ferramenta na detecção de Leptospira pomona por permitir rapidez e sensibilidade, vantagens estas que poderão no futuro ser adicionada aos métodos convencionais de detecção de patógenos no sêmen bovino podendo vir a constituir um 


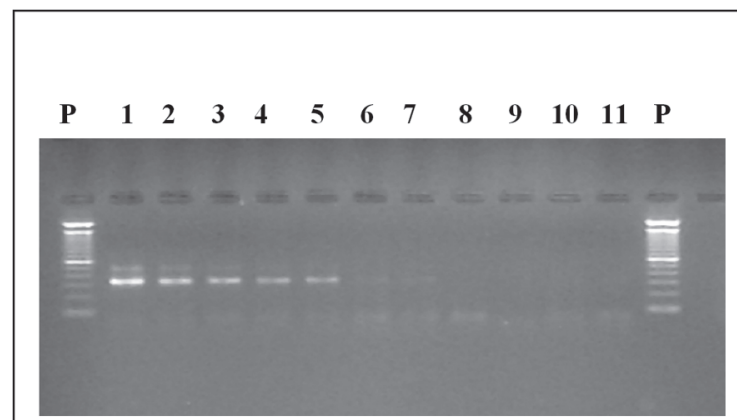

(A)
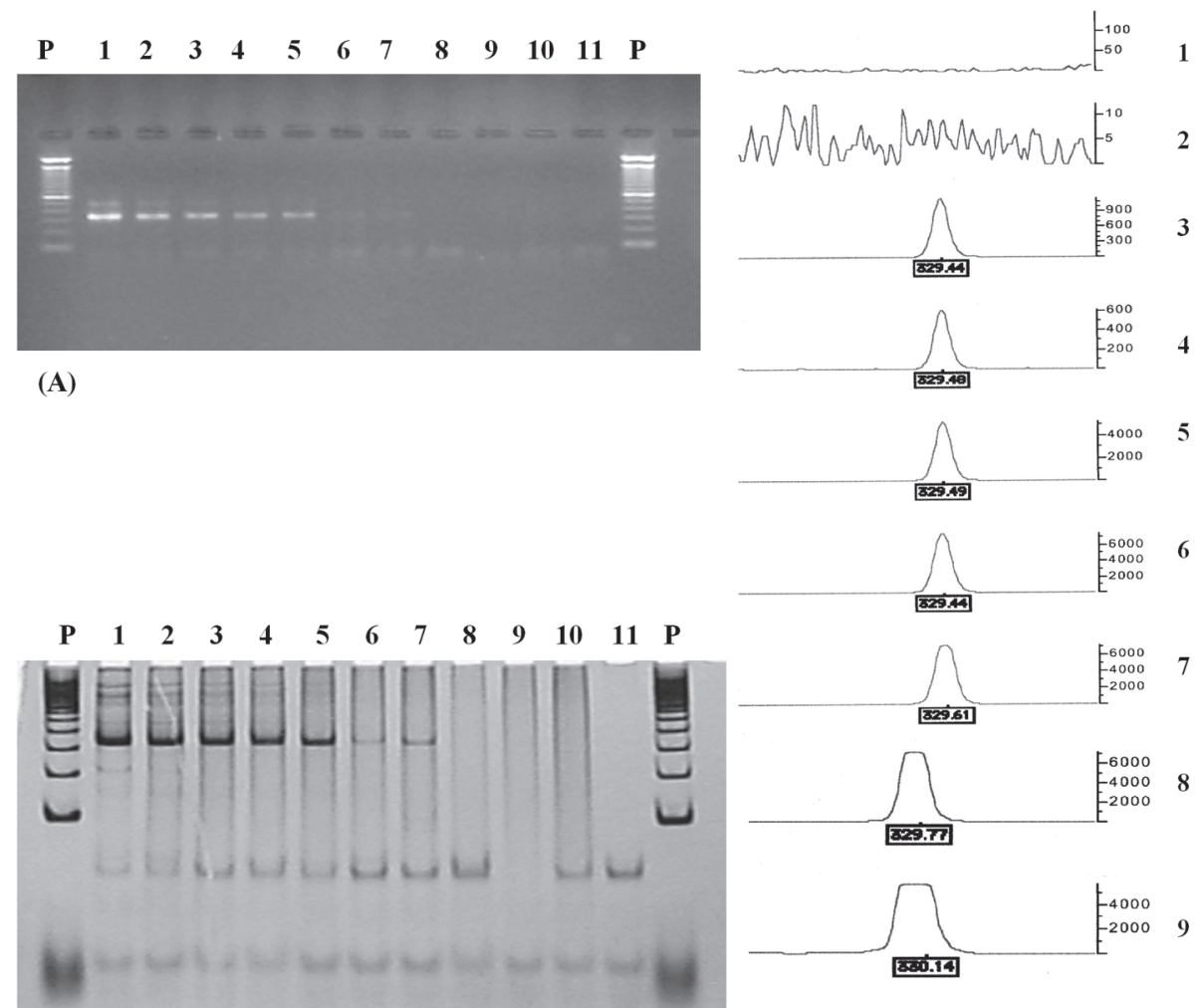

(B)

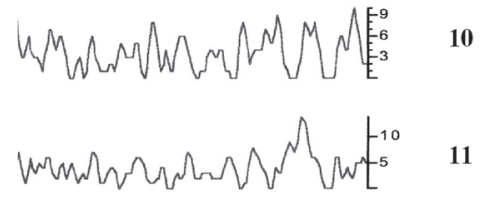

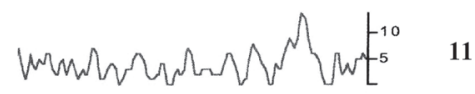

Figura 1 - Análise por três sistemas eletroforéticos da amplificações por PCR em amostras de sêmen infectadas experimentalmente com Leptospira pompna: A e B - agarose 2\% e Acrilamida 8\% respectivamente P) Marcador Molecular 100bp; 1) Controle positivo; 2 a 9) Diferentes diluicões (respectivamente $10^{7} \mathrm{a} 10^{\circ} \mathrm{bact} / \mathrm{ml}$ ) ; 10) Sêmen não contaminado; 11) Controle negativo sem DNA, Figura C-Eletroforese Capilar-1 a 8) Eletroforectogramas diferentes às diluições de $10^{7}$ a $10^{\circ} \mathrm{bact} / \mathrm{ml} \mathrm{e}$ 9) Controle positivo; 10) Sêmen não contaminado; 11) Controle negativo sem DNA

recurso a mais no diagnóstico de agentes infecciosos, para assegurar a produção de sêmen livre de Leptospira em centrais de inseminação artificial.

\section{Agradecimentos}

A Fundação de Apoio a Pesquisa do
Estado de São Paulo - FAPESP (processo $\left.\mathrm{n}^{\circ} 01 / 05486-1\right)$; Sérgio Oliveira do Laboratório IRFA-Química e Biotecnologia Industrial Ltda pelo fornecimento das bactérias e à Central de Inseminação Artificial Lagoa da Serra Ltda pelo fornecimento das amostras de sêmen.

Braz. J. vet. Res. anim. Sci., São Paulo, v. 43, n. 3, p. 394-399, 2006 


\section{Detection of Leptospira pomona in bovine semen by fluorescent capillary eletrophoresis}

\section{Abstract}

This study was performed in order to evaluate the detection limit of PCR with fluorescent capillary electrophoresis for Leptospira pomona diagnosis in bovine semen. Negative bovine semen samples were artificially contaminated with Leptospira pomona $\left(10^{0}\right.$ to $10^{7}$ bacteria/ $\mathrm{ml}$ ) and DNA was extracted by phenol/chloroform protocol. DNA fragments visualization was done by three electrophoresis methods: under UV light in $2 \%$ agarose gel, silver staining $8 \%$ polyacrylamide gel and fluorescent capillary electrophoresis. The detection limit of capillary electrophoresis for Leptospirapomona was $10^{2}$ bacteria $/ \mathrm{ml}$. Under UV light, in $2 \%$ agarose gel, the detection limit was of $10^{4}$ bacteria/ $\mathrm{ml}$ while for silver stained $8 \%$ polvacrylamide gel it was $10^{2}$ bacteria/ $\mathrm{ml}$. PCR with fluorescent capillary electrophoresis is an efficient and rapid diagnostic test for DNA detection of Leptospira in bovine semen and this can be an important tool for herd and semen sanitary control in artificial insemination centers.

\section{Referências}

1 RICHTZENHAIN, L. J.et al. A multiplex PCR for detection of Brucella spp and Leptospira spp. DNA from aborted bovine fetuses. Veterinary of Microbiology, v. 87, p. 139-147, 2002.

2 BRICKER, B. J. PCR as a diagnostic tool for brucelosis. Veterinary of Microbiology, v. 90, p. 435-446, 2002.

3 RODRIGUES, A. L. B.et al. Sobrevivência da Leptospira interrogans sorovariedade pomona em sêmen bovino experimentalmente contaminado. Revista Brasileira de Reprodução Animal, v. 27, n. 4, p. 636643, 2003.

4 MASRI, S. A. et al. A polymerase chain reaction assay for the detection of Leptospira spp in bovine semen. Canadian Journal of Veterinary Research, v. 61, p. 1520, 1997.

5 HEINEMANN, M. B. Detecção de Leptospira spp em sêmen bovino através da reação em cadeia pela polimerase (PCR). 1995. p. 48 Dissertação (Mestrado) - Faculdade de Medicina Veterinária e Zootecnia Universidade de São Paulo, São Paulo, 1995.

6 CICERONI, L.et al. Differentiation of leptospires of the serogroup pomona by monoclonal antibodies, pulsed-field gel eletrophoresis and arbritrarily primed polymerase chain reaction. Research in Microbiology, v. 153, p. 37-44, 2002.

7 AL-SOUD, W. A.et al. Sample preparation method which facilitates detection of bacteria in blood cultures
Key-words: Semen Bovine. Leptospira. PCR.

Capillary Eletrophoresis. by the polymerase chain reaction. Journal of Microbiology Methods, v. 32, p. 217-224, 1998.

8 PEREIRA, C. A. D.et al. Molecular characterization of canine parvovirus in Brazil by polymerase chain reaction assay. Veterinary of Microbiology, v. 75, p. 127-133, 2000.

9 ROCHA, M. A.et al. A high sensivity-nested PCR assay for BHV-1 detection in semen of naturally infected bulls. Veterinary of Microbiology, v. 63, p. 1-11, 1998.

10 SANGUINETTI, C. J.; DIAS NETO, E.; SIMPSON, A. J. Rapid silver staining and recovery of PCR products separated on polyacrylamide gels. Biotechniques, v. 17, n. 5, p. 914-921, 1994.

11 MOORE, S.; GUNN, M.; WALLS, D. A rapid and sensitive PCR-based diagnostic assay to detect bovine herpesvirus 1 in routine diagnostic submissions. Veterinary of Microbiology, v. 75, p. 145-153, 2000.

12 HEWINSON, G. R.et al. Detection of Chlamydia psittaci DNA in avian clinical samples by polymerase chain reaction. Veterinary of Microbiology, v. 54, p. 155-166, 1997.

13 KHAN, M. A.et al. Detection of Staphylococcus aureus in milk by use of polymerase chain reaction analysis. Australian Veterinary Journal, v. 59, n. 7, p. 807-813, 1998.

14 HEINEMANN, M. B.et al. Detection of leptospires in bovine semen by polymerase chain reaction. Australian Veterinary Journal, v. 77, n. 1, p. 32-34, 1999. 
15 HEINEMANN, M. B.et al. Detection and differentiation of Leptospira spp serovars in bovine semen by polimerase chain reaction and restriction fragment length polymorphism. Veterinary of Microbiology, v. 73, p. 261-267, 2000

16 SAMBROOK, J.; FRITSCH, E.F.; MANIATIS, T. Molecular cloning: a laboratory manual. 2nd. New York: Cold Spring Harbor Laboratory Press, 1989, 956 p.

17 MÉRIEN, F.et al. Polymerase chain reaction for detection of Leptospira spp in clinical samples. Journal of Clinical Microbiology, v. 30, n. 9, p. 2219-2224, 1992.

18 LEAL-KLEVEZAS, D. S.et al. Single-step PCR for detection of Brucella spp. from blood and milk of infected animals. Journal of Clinical Microbiology, v. 33, p. 3087-3090,1995.

19 AMIN, A. S.; HAMDY, M. E. R.; IBRAHIM, A. K. Detection of Brucella Militensis in semen using the polymerase chain reaction assay. Veterinary of Microbiology, v. 85, p. 37-44, 2001.

20 MANTEROLA, L.et al. Evaluation of a PCR test for the diagnosis of Brucella ovis infection in semen samples from rams. Veterinary of Microbiology, v. 92, p. 6572, 2003.

21 SMITS, C. B.et al. Comparison of three polymerase chain reaction methods for routine detection of bovine herpesvirus 1 DNA in fresh bull semen. Journal of Virology Methods, v. 85, p. 65-73, 2000.

22 SONG, J. M.; MOBLEY, J.; VO-DINH, T. Detection of bacterial pathogen DNA usinganintegrated complementary metal oxide semiconductor microchip system with capilary array electrophoresis. Journal of Chromatography B, v. 783, p. 501-508, 2003. 